\title{
ЗАСТОСУВАННЯ МОРФОЛОГІЧНОГО АНАЛІЗУ АРТЕРІАЛЬНИХ ОСЦИЛОГРАМ ДЛЯ ОЦІНКИ ДИНАМІКИ ГЕМОДИНАМІЧНИХ ПОКАЗНИКІВ У ПРОБІ МАРТІНЕ - КУШЕЛЕВСЬКОГО
}

Застосування морфологічного аналізу артеріальних осцилограм для оцінки динаміки гемодинамічних показників у пробі Мартіне - Кушелевського

\section{Д. В. Вакуленко ${ }^{1}$, Л. О. Вакуленко}

Тернопільський національний медичний університет імені І. Я. Горбачевського МОЗ України ${ }^{1}$

Тернопільський національний педагогічний університет імені Володимира Гнатюка²

Резюме. Проба Мартіне - Кушелевського (20 присідань за 30 с) - простий, високоінфоормативний метод вивчення стану серцево-судинної системи (ССC), успішно використовується протягом багатьох десятиліть. Застосування електронних тонометрів дає можливість удосконалити метод, фріксувати частоту серцевих скорочень, артеріальний тиск (AT), артеріальні пульсації упродовж усього дослідження, більш детально оцінити особливості діяльності ССС.

Мета дослідження - вивчити фрункціональну здатність ССС адаптуватися до компресії судин плеча при вимірюванні АТ у стані спокою після проби Мартіне - Кушелевського за допомогою (запропонованого авторами роботи) морфрологічного аналізу артеріальних осцилограм (АОГ) та обґрунтувати його інфрормативність.

Матеріали і методи. Обстежено 89 осіб віком 1855 років без скарг на стан здоров'я. Вивчено показники як самої проби, так і АОГ, зареєстрованих до, після навантаження, через 3 хв відпочинку. Оцінку морфрологічних даних АОГ проводили (відповідно до запропонованих авторами критеріїв) за п'ятибальною системою. Результати порівняно між собою.

Результати. У стані спокою найчастіше реєструвались найкращі, 1-й (28 \%) та 2-й (53 \%) типи АОГ. Після навантаження - 3-й тип (54 \%), який зріс на $37 \%$ за рахунок зменшення відсотка АОГ 1-го та 2-го типів. Після 3 хв відпочинку (навіть при нормотонічному типі реакціі) АОГ мали динаміку як в бік «покращення», так і «погіршення». Нерідко у випадках, коли цифрові показниками проби незначно відрізнялись між собою, реєструвались найрізноманітніші типи АОГ. Найчастіше - при неадекватній реакції АT. Відмічене пов'язане з різними рівнями адаптаційної здатності нервово-рефлекторних механізмів кровообігу до компресії та навантаження, в'язко-пружних властивостей судинної стінки, що підтверджується морфологічним аналізом АОГ.
Application of morphological analysis of arterial oscillographs for evaluation of dynamics of hemodynamic indicators in Martine-Kushelev sample

Vakulenko D. V. ${ }^{1}$, Vakulenko L. O. $^{2}$

I. Horbachevsky Ternopil National Medical University ${ }^{1}$ Volodymyr Hnatiuk Ternopil National Pedagogical University ${ }^{2}$

e-mail: vakulenko@ tdmu.edu.ua

Summary. The Martine-Kushelevsky test (20 squats in $30 \mathrm{~s}$ ) is a simple, highly informative method of studying the state of the cardiovascular system (CVS), successfully used for many decades. The use of electronic tonometers makes it possible to improve the method, record heart rate, blood pressure ( $B P)$, blood pulsations throughout the study, to assess in more detail the features of the CVS.

The aim of the study - to learn the functional ability of CVS to adapt to the compression of the vessels of the shoulder when measuring blood pressure at rest, after the Martin-Kushelevsky test using (proposed by the authors) morphological analysis of arterial oscillograms (AOG) and justify its informativeness.

Materials and Methods. 105 people aged 18-55 were examined, without any health complaints. The indicators of both the sample itself and AOG, registered before, after exercise, after 3 minutes of rest, were studied. The morphological data of AOG were evaluated (according to the criteria proposed by the authors) according to a fivepoint system. The results are comparable.

Results. The best, type 1 (28\%) and 2 (53\%) of AOG were most often registered at rest. After exercise - type 3 (54\%), which increased by $37 \%$ due to a decrease in the percentage of AOG type 1 and type 2. After 3 minutes of rest (even with the normotonic type of reaction) AOG had dynamics in the direction of "improvement" and "deterioration". Often, in cases when the digital indicators of the sample differed slightly from each other, a variety of types of AOG were registered. Most often with an inadequate blood pressure response. It is noted associated with different levels of adaptive capacity of the neuro-reflex mechanisms of blood circulation to compression and loading, viscoelastic properties of the vascular wall, which is confirmed by morphological analysis of $A O G$. 
Висновки. Застосування морфологічного аналізу АОГ при проведенні проби Мартіне - Кушелевського дає можливість більш детально оцінити стан гемодинамічних процесів обстежених, їх рівень здоров'я та адаптаційні можливості, завчасно діагностувати початкові відхилення від меж норми.

Ключові слова: морфологічний аналіз артеріальних осцилограм; проба Мартіне-Кушелевського.

\section{ВСТУП}

Значне «помолодшання» та зростання смертності від захворювань серцево-судинної системи (ССС) свідчить про те, що сьогодні суспільство не має ефективних технологій профрілактики, раннього виявлення, лікування цих небезпечних захворювань. Відмічене диктує необхідність пошуку нових, удосконалення уже існуючих засобів діагностики, профрілактики, лікування захворювань ССС. Серед них стратегія ранньої діагностики і профрілактики залишається основною [1].

Останнім часом дещо зменшилась частота застосування проби Мартіне - Кушелевського, яку використовують протягом багатьох десятиліть [3-5] та не втратила своєї актуальності й у наш час [1]. Проба відповідає основним вимогам до проведення фрункціональних проб. Перш за все, бути однотипними, стандартними і дозованими, що дає можливість порівнювати дані, які отримані у різних осіб або в однієї людини у різні періоди часу, тобто в динаміці. Крім того, бути цілком безпечними і водночас достатньо інформативними, а також простими і доступними, не вимагати особливих навичок для їх виконання [2]. Використовують при індивідуальних та масових обстеженнях. Дає можливість оцінити гемодинаміку осіб різних вікових груп не лише фрізкультурників та спортсменів, але й осіб із відхиленнями у стані здоров'я, завчасно діагностувати початкові прояви відхилень від меж норми [2, 6]. При проведенні проби Мартіне - Кушелевського використовують стандартне фрізичне навантаження - 20 присідань за 30 с. Методи ії проведення, оцінки, критерії норми, причини появи станів для яких вони характерні - загальноприйняті. Вони висвітлені в монографріях, статтях, навчальній літературі [2-7].

Застосування електронних тонометрів при цьому дає можливість фріксувати показники частоти серцевих скорочень (ЧСС), артеріального тиску (АТ) та артеріальні пульсації упродовж усього дослідження і як результат - більш детально оцінити особливості роботи серця як єдиного гемодинамічного насоса й артеріальних судин, тобто апарату кровообігу в цілому [2].

Метою дослідження було вивчити фрункціональну здатність серцево-судинної системи адап-
Conclusions. The use of morphological analysis of AOG during the Martine-Kushelevsky test makes it possible to assess in more detail the state of hemodynamic processes of the subjects, their level of health and adaptive capacity, to diagnose the initial deviations from normal.

Key words: morphological analysis of arterial oscillograms; Martine-Kushelevsky test.

туватися до компресії судин плеча при вимірюванні артеріального тиску в стані спокою та після проведення проби Мартіне - Кушелевського за допомогою (запропонованих авторами роботи) інформаційних технологій морфологічного аналізу артеріальних осцилограм (АОГ) та обґрунтувати їх інфрормативність.

\section{МАТЕРІАЛИ I МЕТОДИ}

Обстежено 105 практично здорових осіб чоловічої та жіночої статей віком 18-55 років без скарг на стан здоров'я за власним бажанням та письмовою згодою. Відмічені вікові розбіжності дали можливість отримати різноманітні реакції на фрізичне навантаження за результатами проби Мартіне Кушелевського та морфологічного аналізу АОГ обстежених. АОГ реєстрували при вимірюванні АТ до навантаження, після 20 присідань за 30 с та через 3 хв відпочинку.

У зв'язку з відсутністю подібних досліджень, для морфологічного аналізу осцилограми використано інфрормацію, впроваджену в плетизмографії і реографрії [8] та логічно-візуальні, наукові, теоретичні висновки авторів за результатами аналізу 2500 АОГ у 380 здорових [9].

Морфологічний аналіз АОГ проводили шляхом візуального аналізу та за допомогою математичного аналізу якості АОГ.

При візуальному аналізі виконували загальну візуальну характеристику усієї осцилограми та її окремих пульсацій. Використано розроблені авторами критерії вагової оцінки осцилограми, диореренційованої за 5 ступенями відхилення від ознак, прийнятих нами за норму (рис. 1). При цьому кількість балів зростала від 1 до 5 в міру збільшення кількості відхилень від прийнятої норми.

До 1 типу віднесено АОГ із стандартною формою окремих пульсацій: анакрота, катакрота, дикротичний зубець (його локалізація та розміри залежить від срази компресії) [9]. Звертали увагу на ритмічність пульсацій, гармонійність зростання і спадання їх амплітуд, 2 одакові максимальні амплітуди, які зберігаються, незважаючи на зростання компресії. Відмічене пов'язано із задовільним станом ССС, нервово-рефрлекторних механізмів регуляції кровообігу та в'язко-пружних властивостей судинної стінки обстеженого (8). Для АОГ 2; 3; 4 типів притаманні
Вісник медичних і біологічних досліджень Bulletin of Medical and Biological Research
$2(8), 2021$ 
1-й тип

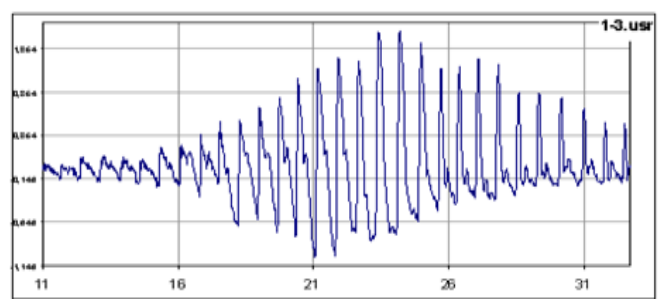

3 тип

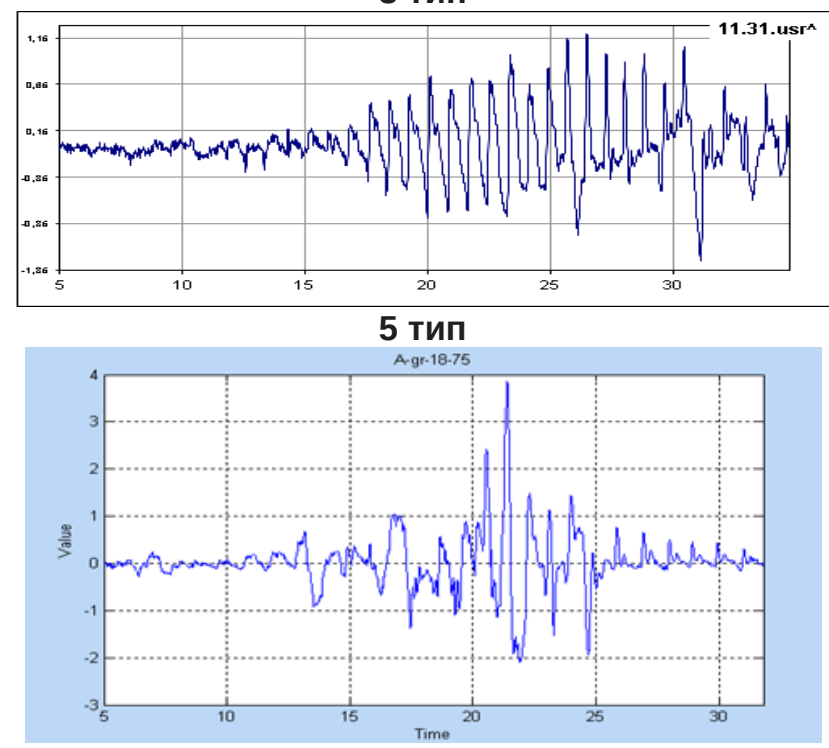

2-й тип

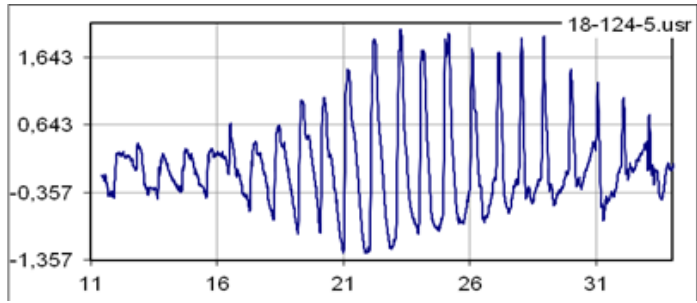

4 тип

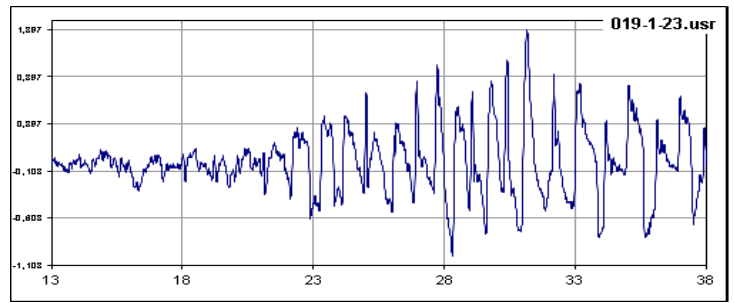

Рис. 1. Типи осцилограм, диференційованих за ритмічністю пульсацій, їх формою та динамікою зростання та спадання амплітуд.

Примітка. По осі $\mathrm{X}$ - час реєстрації осцилограми (с), по осі $\mathrm{Y}$ значення коливань тиску в манжеті під впливом пульсацій судинної стінки артерії (мм рт. ст.).

різні ступені відхилення від вищезазначених ознак норми під час окремих чи усіх фраз компресії. На АОГ 5 типу спотворені форми як окремих пульсацій, так і усієї пульсограми. Відхилення від норми на АОГ 2; 3; 4; 5 типів пов'язані з різним ступенем порушення функціонального стану ССС та автономної нервової системи (АНC), адаптаційної здатності нервово-рефлекторних механізмів кровообігу до компресії, в'язкопружних властивостей судинної стінки [8, 9, 10].

При математичному аналізі морфологічних характеристик використано 9 наступних критеріїв. M1 - якість адаптації на початку компресії (за аналізом динаміки зростання та спадання амплітуди пульсацій до діастолічного тиску). М2 - якість адаптації під час компресії (аналіз динаміки зростання та спадання амплітуди пульсацій від діастолічного тиску і до кінця компресії). МЗ - порушення ритмічності (кількісна оцінка порушення ритмічності пульсацій). M4 - еластичність судин (кількість максимальних за амплітудою осциляцій). M5 - тонус судин на початку компресії (фрорма верхніх екстремумів осциляцій на початку компресії. М6 - тонус судин (оцінка осцилограми за наявністю дрібних осциляцій). М7 - рівень збудливості судинної стінки (оцінка за величиною амплітуди, кількістю та наявністю екстремальних 3 нерівномірним збільшенням амплітуди осциляцій). М8 - оцінка динаміки зміни площі висхідної частини осциляцій. М9 - оцінка динаміки зміни площі низхідної частини осциляцій. За рівнем

відхилення від запропонованих нами меж норми (визначених за аналізом 3500 АОГ) кожен з критеріїв оцінений за п'ятибальною системою. Кількість балів зростала в міру збільшення кількості відхилень від критеріїв норми. При цьому вивчено й оцінено відмічені критерії у кожного з обстежених, усієї групи та середні показники за кожним з них.

Статистичне опрацювання результатів проводили 3 використанням комп'ютерної програми Statistica, застосовували критерій Стьюдента при нормально розподілених даних в іншому випадку - метод Вілкоксона. Зміни показників вважали статистично значущими при $p<0,05$.

\section{РЕЗУЛЬТАТИ Й ОБГОВОРЕННЯ}

Оцінку результатів проби Мартіне - Кушелевського за типами реакції ССС представлені у таблиці 1.

Перехідні типи визначені у 91 осіб. Більшості 3 них була притаманна збудливість пульсу до 80 \%, час її відновлення - до 3 хв, що свідчить про задовільну фрункціональну здатність кардіального чинника у гемодинамічних процесах організму обстежених. Серед них найчастіше зустрічались відхилення від норми показників АТ. Їм було характерне збільшення часу відновлення АT, більше 3 хв: АТ систолічного (АТc) у $31 \%$ та АТ діастолічного (АТд) у $13 \%$ обстежених. АТд після навантаження підвищився у 26 \% випадків. Відмічене пов'язано 3 
Таблиця 1. Типи реакції серцево-судинної системи на функціональну пробу Мартіне - Кушелевського

\begin{tabular}{c|l|c|c|c|c|c|c}
\hline \multirow{2}{*}{ № } & \multirow{2}{*}{ Критерій } & \multicolumn{5}{|c}{ Тип реакції $(\mathrm{n}=88)$} & \multirow{2}{*}{ несприятливий } \\
\cline { 3 - 8 } & & сприятливий & \multicolumn{3}{|c}{ перехідний } \\
\cline { 3 - 8 } & нормотонічний & гіпертонічний & дистонічний & астенічний & східчастий & \\
\hline 1 & Кількість & 17 & 6 & 0 & 2 & 1 & 62 \\
\hline 2 & Відсоток & 19 & 7 & 0 & 3 & 1 & 70 \\
\hline
\end{tabular}

різними рівнями адаптаційної здатності нервовореорлекторних механізмів кровообігу до компресії та навантаження, в'язко-пружних властивостей судинної стінки, що підтверджується подальшим аналізом АОГ $[8,10]$.

\section{Показники морфологічного аналізу}

Підрахунок результатів візуального аналізу АОГ засвідчив чітку динаміку їх якісних характеристик після навантаження (табл. 2).

Аналіз АОГ до та після проби Мартіне - Кушелевського засвідчив найрізноманітнішу динаміку візуальних морфологічних характеристик в процесі обстеження. У стані спокою найчастіше зустрічався 1-й (28 \%) та 2-й (53 \%) типи АОГ. Після навантаження переважав 3-й тип (54\%), який зріс на $37 \%$ за рахунок зменшення відсотка 1 типу (28 \%) та 2 типу (16 \%). Таким чином, під час фрізичного навантаження зростають вимоги до адаптаційної здатності організму, що проявляється у «погіршенні» якості АОГ, яке можна оцінити візуально. Після 3 хв відпочинку навіть при нормотонічному типі реакції на фрізичне навантаження АОГ мали динаміку як в бік «покращення», так і «погіршення». Нерідко у випадках, коли цифрові показниками проби незначно відрізнялись між собою, реєструвались найрізноманітніші типи АОГ. Найчастіше - при неадекватній реакції АТ. Відмічене пов'язано з різними рівнями адаптаційної здатності нервово-рефрлекторних механізмів кровообігу до компресії та навантаження, в'язко-пружних властивостей судинної стінки.

Для прикладу використано АОГ обстежених № 92 та № 101 (рис. 2).

Як видно з рисунків у обстеженого № 92 на трьох АОГ збережені ритмічні пульсації на початку компресії, при цьому чітко сорормовані вершини гармонійного зростання пульсацій у процесі зростання компресії, 3 максимальні пульсації та рівномірне зменшення амплітуд у процесі зростання компресії плеча у фразі систоли. Після фрізичного навантаження реєструється гармонійне зростання частоти пульсацій та її зменшення після відпочинку.

У правому стовпчику (№ 101) звертає на себе увагу гармонійність пульсацій до навантаження 3 поодиноким порушенням ритму на етапі зменшення амплітуди пульсацій (2 тип). При цьому різниця між № 92 та № 101 незначна. Після навантаження у № 101 - значне погіршення усіх візуальних морорологічних характеристик (4 тип) та покращення (3 тип) після відпочинку. При сприятливому типі реакції чСС на пробу Мартіне - Кушелевського дала можливість засвідчити функціональний характер відмічених порушень,

Для порівняння фрункціональних можливостей обстеженого № 92 та № 101 демонструємо протоколи проведення та оцінки результатів проби Мартіне - Кушелевського (табл. 3), які зіставили із зареєстрованими АОГ.

При порівняльному аналізі обох протоколів, зафріксовані результати можна віднести до перехідного типу за рахунок наступних відхилень від стандартів (нормотонічного типу). В першому випадку (№ 92) - це відновлення пульсу до показника, нижчого від вихідного уже на початку 2 хв. При цьому АТ на тлі задовільної реакції безпосередньо на навантаження, не відновився за 4 хв. У другому випадку (№ 101) маємо швидке відновлення пульсу уже на 2 хв, що свідчить про високий рівень адаптаційних можливостей ССС до фрізичного навантаження. Проте звертає на себе увагу стан АТ. Низький пульсовий тиск у стані спокою (20 мм рт. ст.), що зумовлено показником АТд, який вище верхніх показників норми. Після навантаження - значне зростання АТс

Таблиця 2. Результатів візуального аналізу типів артеріальних осцилограм залежно від періоду обстеження

\begin{tabular}{|c|c|c|c|c|c|c|c|c|c|c|c|c|}
\hline \multirow{4}{*}{$\begin{array}{l}\text { Тип } \\
\text { АО }\end{array}$} & \multicolumn{12}{|c|}{ Період обстеження, показники (n=83) } \\
\hline & \multirow{2}{*}{\multicolumn{2}{|c|}{$\begin{array}{c}\text { до наванта- } \\
\text { ження } \\
(1) \\
\end{array}$}} & \multicolumn{4}{|c|}{ після навантаження (2) } & \multicolumn{6}{|c|}{ через 3 хв відпочинку (3) } \\
\hline & & & \multicolumn{2}{|c|}{ показник } & \multicolumn{2}{|c|}{ різниця 1-2 } & \multicolumn{2}{|c|}{ показник } & \multicolumn{2}{|c|}{ різниця 2-3 } & \multicolumn{2}{|c|}{ різниця 1-3 } \\
\hline & кількість & $\%$ & кількість & $\%$ & $\%$ & $p$ & кількість & $\%$ & $\%$ & $p$ & $\%$ & $p$ \\
\hline 1 & 24 & 28 & 0 & 0 & -28 & $<0,05$ & 2 & 3 & 3 & $>0,05$ & -26 & $<0,05$ \\
\hline 2 & 44 & 53 & 31 & 37 & -16 & $<0,05$ & 35 & 42 & 5 & $>0,05$ & -11 & $<0,05$ \\
\hline 3 & 14 & 17 & 45 & 54 & 37 & $<0,05$ & 41 & 49 & -5 & $>0,05$ & 3 & $<0,05$ \\
\hline 4 & 1 & 1 & 5 & 6 & 5 & $>0,05$ & 5 & 7 & 1 & $>0,05$ & 6 & $>0,05$ \\
\hline 5 & & 0 & 2 & 2 & 2 & $>0,05$ & & 0 & -2 & $>0,05$ & 0 & 0 \\
\hline
\end{tabular}


Обстежений № 92
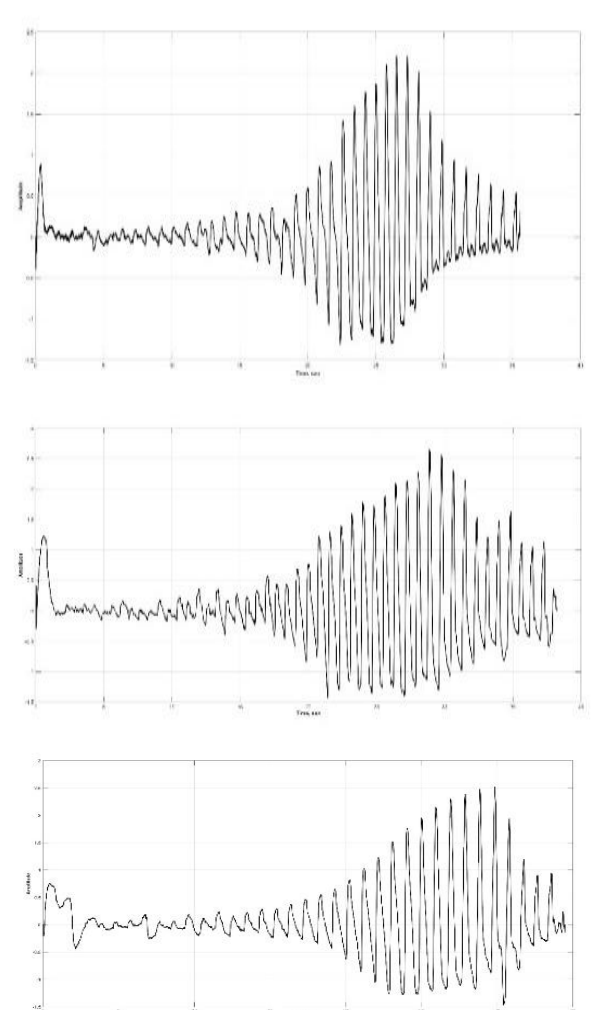

1

Обстежений № 101

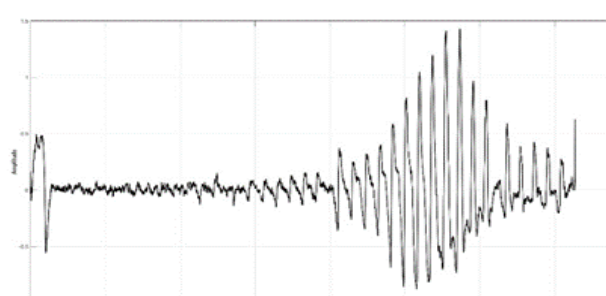

2

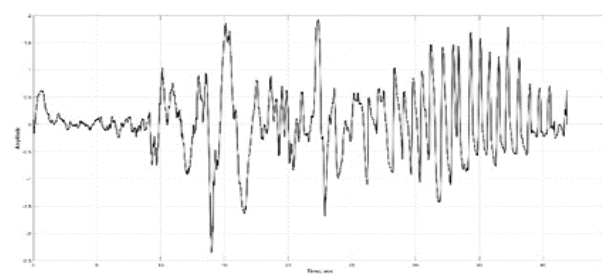

3

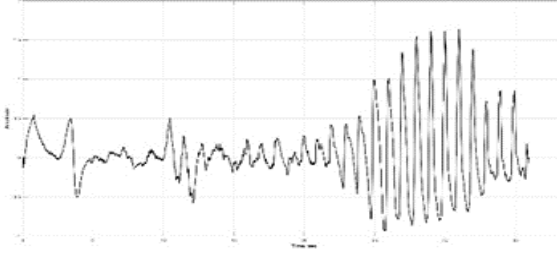

Рис. 2. Порівняльний аналіз динаміки артеріальних пульсацій: 1 - до навантаження, 2 - після навантаження 3 - через 3 хв відпочинку в процесі проведення проби Мартіне - Кушелевського

Примітка. По осі X - час реєстрації осцилограми (c), по осі Ү - значення коливань тиску в манжеті під впливом пульсацій судинної стінки артерії.

Таблиця 3. Протоколи проби Мартіне - Кушелевського

\begin{tabular}{|c|c|c|c|c|c|c|c|c|c|c|c|c|c|}
\hline \multicolumn{14}{|c|}{ А. Протокол проведення проби Мартіне - Кушелевського } \\
\hline \multirow{3}{*}{$\begin{array}{l}\text { Чac } \\
\text { (c) }\end{array}$} & \multicolumn{6}{|c|}{ Обстежений № 92} & \multirow{3}{*}{$\begin{array}{c}4 \mathrm{ac} \\
\text { (c) }\end{array}$} & \multicolumn{6}{|c|}{ Обстежений № 101} \\
\hline & \multicolumn{2}{|c|}{$\begin{array}{c}\text { до наван- } \\
\text { таження }\end{array}$} & \multicolumn{4}{|c|}{ після навантаження } & & \multicolumn{2}{|c|}{$\begin{array}{c}\text { до наванта- } \\
\text { ження }\end{array}$} & \multicolumn{4}{|c|}{ після навантаження } \\
\hline & $\begin{array}{l}\text { पCC, } \\
\text { ATC }\end{array}$ & АТд & $1 \times B$ & $2 \times B$ & $3 \times \mathrm{B}$ & $4 \times B$ & & $\begin{array}{l}\text { पCC, } \\
\text { ATC }\end{array}$ & АТд & $1 \times B$ & $2 \times B$ & $3 \times \mathrm{B}$ & $4 \times \mathrm{B}$ \\
\hline 10 & 12 & & 16 & 12 & 11 & 11 & 10 & 11 & & 15 & 11 & 11 & \\
\hline 20 & & & & 11 & 11 & 11 & 20 & 11 & & & 11 & 11 & \\
\hline 30 & & & & 11 & 11 & 11 & 30 & 11 & & & 12 & 11 & \\
\hline 40 & & & & 11 & 11 & 11 & 40 & & & & 12 & & \\
\hline 50 & & & & 11 & 11 & & 50 & & & & 11 & & \\
\hline 60 & & & & 11 & 11 & & 60 & & & & 11 & & \\
\hline ATC & 114 & & 134 & & & 125 & ATc & 111 & & 162 & & 133 & \\
\hline Атд & & 84 & 76 & & & 89 & Атд & & 91 & 87 & & 89 & \\
\hline \multicolumn{14}{|c|}{ Б. Оцінка результатів проби Мартіне - Кушелевського } \\
\hline \multicolumn{5}{|c|}{ Критерій оцінки } & \multicolumn{4}{|c|}{ Обстежений № 92} & \multicolumn{5}{|c|}{ Обстежений № 101} \\
\hline \multicolumn{5}{|c|}{ Збудливість пульсу } & \multicolumn{4}{|c|}{$33 \%$} & \multicolumn{5}{|c|}{$36 \%$} \\
\hline \multicolumn{5}{|c|}{ Час відновлення пульсу } & \multicolumn{4}{|c|}{1 хв $20 \mathrm{c}$} & \multicolumn{5}{|c|}{$1 \times \mathrm{xB} 50 \mathrm{c}$} \\
\hline \multicolumn{5}{|c|}{ Реакція АТс } & \multicolumn{4}{|c|}{$17 \%$} & \multicolumn{5}{|c|}{$45 \%$} \\
\hline \multicolumn{5}{|c|}{ Реакція АТд } & \multicolumn{4}{|c|}{$-9 \%$} & \multicolumn{5}{|c|}{$-5 \%$} \\
\hline \multicolumn{5}{|c|}{ Час відновлення АТ } & \multicolumn{4}{|c|}{$>3 \times B$} & \multicolumn{5}{|c|}{$>3 \times B$} \\
\hline \multicolumn{5}{|c|}{ Тип реакції } & \multicolumn{4}{|c|}{ Перехідний } & \multicolumn{5}{|c|}{ Перехідний } \\
\hline
\end{tabular}


і неповне його відновлення через 3 хв. Якщо порівняти особливості динаміки візуальних морфологічних характеристик артеріальних пульсацій у № 101, то чітко простежується значне їх погіршення безпосередньо після навантаження (з 1 до 4 типу) та незначне покращення - через 3 хв відпочинку (3 тип). При адекватній реакції частоти пульсу в обстеженого № 101 можемо виключити обмеження фрункціональної здатності серцевого та пов'язати 3 судинним компонентом системи кровообігу, зумовлений дисфункцією окремих ланок АНС. Таким чином, застосування АОГ при проведенні проби Мартіне - Кушелевського дає можливість більш детально оцінити стан серцево-судинної системи та визначити причини відхилень окремих показників від нормотонічного типу.

Вивчення результатів математичного аналізу морорологічних характеристик АОГ дали можливість детальніше (порівняно з візуальним) оцінити АОГ за більшою кількістю (9) критеріїв в різних фразах компресії плеча. За середніми показниками 9 критеріїв спостерігалась тенденція, яка отримана і при візуальному аналізі АОГ: до навантаження вони оцінені в 2,8 бала, після навантаження їх якість погіршувалась, зростали до 3,5, через 3 хв наблизились до вихідних, 2,98 бала. Нерідко у випадках навіть нормотонічного типу реакції на пробу Мартіне - Ку- шелевського, морфологічні характеристики АОГ не відновлювались до початкових (рис. 2, табл. 3), що підтверджує високу інформативність запропонованого методу морорологічного аналізу АО. За характером пульсацій мали можливість судити про тонус та прохідність судин, стан серцево-судинної та автономної нервової систем, артеріальний тиск, нервоворефлекторні механізми регуляції кровообігу та в'язко-пружні властивості судинної стінки [8, 10].

Фізіологічна інтерпретація аналізу та оцінки типу артеріальних осцилограм дали можливість зіставити їх 35 варіантами градації рівня здоров'я створеними за фрізіологічною інтерпретацією варіабельності серцевого ритму електрокардіосигналу Р. М. Баєвським (табл. 4).

Відповідно до використаної інтерпретації Р. М. Кушелевського автори отримали можливість за показниками АОГ оцінити рівень здоров'я та адаптаційні можливості організму обстежених та запропонувати рекомендації до їх корекції, які відображені у таблиці 3. Відмічена інформація може бути використана сімейним лікарем для оцінки реабілітаційного потенціалу та подальшої його корекції у разі необхідності.

У перспективі - проведення часового, спектрального, кореляційного аналізу АОГ в процесі проведення проби Мартіне - Кушелевського.

Таблиця 4. Морфологічна характеристика типу артеріальних осцилограм обстежених до та після проби Мартіне Кушелевського, їх фрізіологічна інтерпретація (за Р. М. Баєвським)

\begin{tabular}{l|c|c|l|l}
\hline $\begin{array}{c}\text { Варіант } \\
\text { градації }\end{array}$ & $\begin{array}{c}\text { До } \\
\text { навантаженя, \% }\end{array}$ & $\begin{array}{c}\text { Після } \\
\text { навантаження, \% }\end{array}$ & \multicolumn{1}{|c|}{$\begin{array}{c}\text { Рівень здоров'я } \\
\text { та адаптації }\end{array}$} & \multicolumn{1}{|l}{ Рекомендації } \\
\hline 1 тип & 28 & 0 & $\begin{array}{l}\text { 3доровий, оптимальна } \\
\text { адаптація }\end{array}$ & $\begin{array}{l}\text { Підтримувати здоровий } \\
\text { спосіб життя }\end{array}$ \\
\hline 2 тип & 53 & 37 & $\begin{array}{l}\text { Практично здоровий, на- } \\
\text { пружена адаптація }\end{array}$ & Корекція способу життя \\
\hline 3 тип & 17 & 54 & $\begin{array}{l}\text { Умовно здоровий, перена- } \\
\text { пруження адаптації }\end{array}$ & $\begin{array}{l}\text { Превентивна реабіліта- } \\
\text { ція }\end{array}$ \\
\hline 4 тип & 1 & 6 & $\begin{array}{l}\text { Стан передхвороби, зрив } \\
\text { адаптації }\end{array}$ & $\begin{array}{l}\text { Детальне обстеження, } \\
\text { вивчення стану ссс }\end{array}$ \\
\hline 5 тип & 0 & $\begin{array}{l}\text { Хворий,(адаптація до по- } \\
\text { рушень }\end{array}$ & $\begin{array}{l}\text { Детальне обстеження та } \\
\text { лікування }\end{array}$ \\
\hline
\end{tabular}

\section{ВИСНОВКИ}

Проба Мартіне - Кушелевського - доступний, інорормативний валідний метод, який застосовується при масових обстеженнях і не втратив своєї актуальності на даний час. Дає можливість оцінити адаптаційну здатність серцево-судинної системи осіб різних вікових груп, завчасно діагностувати початкові прояви відхилень від меж норми та спрямувати обстежених до поглибленого обстеження [2, 6].

Аналіз АОГ до та після проби Мартіне - Кушелевського засвідчив найрізноманітнішу динаміку морорологічних характеристик АОГ в процесі обстеження. Неоднорідна реакція гладкої мускулатури судин на компресію свідчить про різні рівні чутливос- ті рецепторних приборів баро- і хеморецепторів, які контролюють різні параметри кровообігу та гнучкості пристосувальної здатності серця і судин до змінюваних умов зовнішнього середовища.

Застосування візуального та математичного аналізу морсрологічних характеристик АОГ дає можливість більш детально (порівняно з оцінкою проби Мартіне - Кушелевського) оцінити стан гемодинамічних процесів обстежених, їх рівень здоров'я та адаптаційні можливості. Значно розширює сферу її використання. Фізіологічна та клінічна інтерпретація отриманих даних дає можливість ефективніше вирішувати завдання діагностичного і прогностичного профрілю, оцінки ффункціонального стану, контролю
ISSN 2706-6282(print) ISSN 2706-6290(online)
Вісник медичних і біологічних досліджень Bulletin of Medical and Biological Research
$2(8), 2021$ 
ефективності лікувально-профрілактичних впливів, прогнозування фрункціональних станів при профвідборі і визначенні просрпидатності. Відмічене є діє- вим засобом профрілактики «помолодшання» захворювань серцево-судинної системи, попередження судинних катастрофр та інших захворювань.

\section{СПИСОК ЛІТЕРАТУРИ}

1. Апанасенко Г. Л. Введение в новую парадигму здоровоохранения. Здоровье и фитнес / Г. Л. Апанасенко. - К. : Изд-во ООО «Юрка Любченка», 2020. - 287 с. Url: https:// ja-jp.facebook.com/UFM.org.ua/posts/1340189982846209/

2. Фізична, реабілітаційна та спортивна медицина : Підручник для студентів і лікарів / за заг. ред. В. М. Сокрута. - Краматорськ : Каштан, 2019. - 480 с. URL: https://new.meduniv.Iviv.ua/uploads/repository/kaf/ kaf_sportmed/04.1.\%20Navhalno_metod_literatura/01.1\%20 Fizichna_reabilitaziy_sport_med/Fisyhna\%2C\%20 reabilitaziyna\%20sportmedyz.pdf.

3. Тесты в спортивной практике : пер. с нем. / Х. Бубе, Г. Фэк, Х. Штюблер, Ф. Трогш. - М. : Физкультура и спорт, 1968. - 239 с. URL: https://search.rsl.ru/ru/ record/01006224651

4. Руководство по кинезитерапии / П. Слипчев, Л. Бонев, С. Банква [и др.] : пер с болгарского Е. Колачевой. - София : Медицина и фризкультура. - 1978. - 355 с. URL: https://www.studmed.ru/bonev-I-slynchev-p-redrukovodstvo-po-kineziterapii_09362c2dd0e.html

5. Фізична реабілітація, спортивна медицина : підручник для студ. вищих мед. навч. закладів / В. В. Абрамов, В. В. Клапчук, О. Б. Неханевич, А. В. Магльований [та ін.] ; за ред. профресора В. В. Абрамова та доцента О. Л. Смирнової. - Дніпропетровськ, Журфонд. - 2014. - 456 c. URL: http://irbis-nbuv.gov.ua/cgi-bin/irbis nbuv/ cgiirbis_64.exe?C21COM=S\&I21DBN=REF\&P21DBN=R EF\&S21FMT=fullwebr\&S21ALL=\%28\%3C.\%3ET\%3D\%D 0\%A4\%D1\%96\%D0\%B7\%D0\%B8\%D1\%87\%D0\%BD\% D0\%B0\%20\%D1\%80\%D0\%B5\%D0\%B0\%D0\%B1\%D1\%96\%D0\%BB\%D1\%96\%D1\%82\%D0\%B0\%D1\%86\%D1\%9 6\%D1\%8F,\%20\%D1\%81\%D0\%BF\%D0\%BE\%D1\%80\%D 1\%82\%D0\%B8\%D0\%B2\%D0\%BD\%D0\%B0\%20\%D0\%B C\%D0\%B5\%D0\%B4\%D0\%B8\%D1\%86\%D0\%B8\%D0\%B
D\%D0\%B0\$\%3C.\%3E\%29\&FT REQUEST=\&FT PREFIX $=\& Z 21 \mathrm{ID}=\& S 21 \mathrm{STN}=1 \& \mathrm{~S} 21 \mathrm{RE} \overline{\mathrm{F}}=10 \& \mathrm{~S} 21 \mathrm{CNR}=20$

6. Основи реабілітації, фрізичної терапії, ерготерапії : піручник / [ Л. О. Вакуленко, В. В. Клапчук, Д. В. Вакуленко та ін.] ; заг. ред. Л. О. Вакуленко, В. В. Клапчука. - Тернопіль : ТДМУ. - 2019. - 372 с. URL: https://library. gov.ua/osnovy-reabilitatsiyi-fizychnoyi-terapiyi-ergoterapiyi/

7. Варіанти інтерпретації показників проби Мартіне - Кушелевського / Д. В. Вакуленко, С. 3. Храбра, О. Р. Барладин [та ін.] // The 8th International scientific and practical conference «Fundamental and applied research in the modern world» (March 17-19, 2021) BoScience Publisher, Boston, USA. 2. - P. 375-385. URL: https://sci-conf. com.ua/viii-mezhdunarodnaya-nauchno-prakticheskayakonferentsiya-fundamental-and-applied-research-in-themodern-world-17-19-marta-2021-goda-boston-ssha-arhiv/

8. Caro C. G. The mechanics of the circulation. 2nd ed. / C. G Caro, T. J. Pedley, R. C. Schroter et al. // London: Cambridge University Press; 2012. - 400 c. URL: https://www.ama zon.com/Mechanics-Circulation-C-G-Caro/dp/0521151775

9. Вакуленко Д. В. Інформаційна система морфологічного, часового, частотного та кореляційного аналізу артеріальних осцилограм у фрізичній реабілітації : монограсрія / Д. В. Вакуленко. - Тернопіль : ТДМУ, 2015. - 212 c. URL: https://www.researchgate.net/publication/290820089_Informacijna_sistema_morfologicnogo_casovogo_spektralnogo_ta_korelacijnogo_analizu_arterialnih_oscilogram_u_fizicnij_reabilitacii

10. Vakulenko Dmytro V. Cardiovascular system adaptability to exercise according to morphological, temporal, spectral and correlation analysis of oscillograms / Dmytro V.Vakulenko, Vasyl P. Martseniuk, Liudmyla O. Vakulenko, // Family Medicine \& Primary Care Review 2019; 21(3): 253-263. URL: https://doi.org/10.5114/fmpcr.2019.88385

\section{REFERENCES}

1. Apanasenko HL An introduction to a new paradigm of health care. Health and fitness. [Введение в новую парадигму здоровоохранения. Здоровье и фритнес] Kyiv: Iz-vo O०० "Yurka Liubchenka"; 2020. Available from: https://ja-jp. facebook.com/UFM.org.ua/posts/1340189982846209/ Russian.

2. Sokrut VM Ed. Physical, rehabilitation and sports medicine: A textbook for students and physicians. [Фізична, реабілітаційна та спортивна медицина: Підручник для студентів і лікарів] Kramatorsk: Kashtan; 2019. Available from: https://new.meduniv.Iviv.ua/uploads/repository/kaf/ kaf_sportmed/04.1.\%20Navhalno_metod_literatura/01.1\%20
Fizichna_reabilitaziy_sport_med/Fisyhna\%2C\%20reabilitaziyna\%20sportmedyz.pdf Ükrainian.

3. Bube Kh, Fek H, Shtyubler Kh, Trogsh F. Tests in sports practice: transl from German. [Тесты в спортивной практике: пер. с нем]. Moscow: Fizkultura i sport; 1968. Available from: https://search.rsl.ru/ru/record/01006224651 Russian.

4. Slipchev P, Bonev L, Bankva S. Guidelines on kinesiotherapy. [Руководство по кинезитерапии] Sofiya: Medity sina i fizkultura; 1978. Available from: https://www.studmed. ru/bonev-I-slynchev-p-red-rukovodstvo-pokineziterapii_09362c2dd0e.html Russian. 
5. Abramov, VV, Klapchuk VV, Nekhanevych OB, Mahliovanyi AV. Physical rehabilitation, sports medicine: a textbook for students of medical schools. [Фізична реабілітація, спортивна медицина : підручник для студ. вищих мед. навч. закладів] Dnipropetrovsk, Zhurfond; 2014. Available from: http://irbis-nbuv.gov.ua/cgi-bin/irbis_nbuv/ cgiirbis_64.exe?C21COM=S\&I21DBN=REF\&P21DBN=RE F\&S21FMT=fullwebr\&S21ALL=\%28\%3C.\%3ET\%3D\%D0\% A4\%D1\%96\%D0\%B7\%D0\%B8\%D1\%87\%D0\%BD\%D0 \%B0\%20\%D1\%80\%D0\%B5\%D0\%B0\%D0\%B1\%D1\%96\% D0\%BB\%D1\%96\%D1\%82\%D0\%B0\%D1\%86\%D1\%96\%D 1\%8F,\%20\%D1\%81\%D0\%BF\%D0\%BE\%D1\%80\%D1\%82 \%D0\%B8\%D0\%B2\%D0\%BD\%D0\%B0\%20\%D0\%BC\%D0 \%B5\%D0\%B4\%D0\%B8\%D1\%86\%D0\%B8\%D0\%BD\%D0 $\%$ B0\$3C.\%3E\%29\&FT_REQUEST=\&FT_PREFIX=\&Z21 $I D=\& S 21 S T N=1 \& S 21 R E F=10 \& S 21 C N R=20$ Ukrainian.

6. Vakulenko LO, Klapchuk VV, Vakulenko DV Basics of rehabilitation, physical therapy, occupational therapy: a handbook. [Основи реабілітації, фрізичної терапії, ерготерапії: піручник] Ternopil: TDMU; 2019. Available from:https://library.gov.ua/osnovy-reabilitatsiyi-fizychnoyiterapiyi-ergoterapiyi/ Ukrainian.

7. Vakulenko DV, Khrabra S.Z., Barladin OR. Variants of interpretation of Martine - Kushelevsky sample indicators. The 8th International scientific and practical conference
"Fundamental and applied research in the modern world" (March 17-19, 2021) BoScience Publisher, Boston, USA. Available from: https://sci-conf.com.ua/viii-mezhdunarodnayanauchno-prakticheskaya-konferentsiya-fundamental-andapplied-research-in-the-modern-world-17-19-marta-2021goda-boston-ssha-arhiv/ Ukrainian.

8. Caro CG, Pedley TJ, Schroter RC. The mechanics of the circulation. 2nd ed. London: Cambridge University Press; 2012. Available from: https://www.amazon.com/MechanicsCirculation-C-G-Caro/dp/0521151775

9. Vakulenko DV Information system of morphological, temporal, frequency and correlation analysis of arterial oscillograms in physical rehabilitation: monograph. [Інформаційна система морфологічного, часового, частотного та кореляційного аналізу артеріальних осцилограм у фрізичній реабілітації: монографрія] Ternopil: TDMU; 2015. Available from: https://www.researchgate.net/publication/290820089_ Informacijna_sistema_morfologicnogo_casovogo_ spektralnogo_ta_korelacijnogo_analizu_arterialnih_ oscilogram_u_fizicnij_reabilitacii Ukrainian.

10. Vakulenko DV, Martseniuk VP, Vakulenko LO. Cardiovascular system adaptability to exercise according to morphological, temporal, spectral and correlation analysis of oscillograms. Family Medicine \& Primary Care Review. 2019;21(3): 253-63. DOI: https://doi.org/10.5114/ fmpcr.2019.88385

Отримано 02.03.21 